\title{
The First Successful Separation of Conjoined Twins in 1689: Some Additions and Corrections
}

\author{
Erwin J. O. Kompanje \\ Department of Neurological Surgery, Erasmus Medical Center Rotterdam, the Netherlands
}

\begin{abstract}
$T_{\text {theser }}^{\text {he }}$ he surgical separation of a pair of conjoined twins in the year 1689 by Johannes Fatio was the subject of a recent article in this journal. The reference used as publication of the case was Fatio's book, Der Arzney Doctor, Helvetisch-Vernüftige Wehe-Mutter, published in 1752, although the case was presented in literature by three earlier sources. Two articles were published in the Miscellanea Curiosa sive Ephemeridum MedicoPhysicarum Germanicarum Academiae Imperialis Leopoldinae Naturae Curiosorum in 1689 by Emanuel König and another in 1690 by Theodor Zwinger who described and illustrated the case in detail. Besides these articles, a Flug Blatt was published on the case between 1689 and 1695. Fatio copied the engraved plate in his book from König's engraving. These two sources should be cited as the first publications on the successful separation of Elisabet and Catherina, and not Fatio's book from 1752.
\end{abstract}

The surgical separation of a pair of conjoined twins in the year 1689 was the subject of a recent article in this journal (Van der Weiden, 2004). The case report, which formed the basis of the article, was found in Johannes Fatio's obstetrical work, Der Arzney Doctor, Helvetisch-Vernüftige Webe-Mutter, published in 1752 . The intention of the article by Van der Weiden was to save the case report, almost certainly the first publication of successful separation of conjoined twins according to the author, from oblivion, and to correct several historical inaccuracies.

The description in Fatio's book, however, is not the first concerning this interesting case. Three other sources published earlier than 1752 exist and the case is mentioned in many teratological handbooks and several articles in medical literature published after 1752. Unfortunately, none of these sources are cited with reference and some incorrect historical conclusions were drawn from Fatio's report. The aim of this article is to provide some additions and corrections to Van der Weiden's article.

\section{Sources Published Earlier Than 1752}

First, we need to mention two articles published in one of the oldest medical journals, the Miscellanea
Curiosa sive Ephemeridum Medico-Physicarum Germanicarum Academiae Imperialis Leopoldinae Naturae Curiosorum (König 1689; Zwinger 1690). These two articles must be considered as the two earliest sources concerning this case. The article of König (König, 1689) is illustrated with the same engraved plate (Figure 1) as Fatio (Figure 3), with some differences. König's plate can be considered as the first engraving of the case, leaving Fatio's plate as a copy from this engraving. In 1689 Johannes Fatio provided the details of the case to Zwinger, which formed the basis of Zwinger's article. The girls depicted on the engraving were named Elisabet (Elisabetham) and Catherina (Catharinam). The mother of the twins, Clementia Meinin (named Clementia Meijerin in Fatio's text), had already given birth to a daughter and a son. The birth of the conjoined twins durated, despite the difficulties, only two hours. Surgeon Samuel Braun consulted Johannes Fatio (Fatius), who in turn consulted Dr Nicolaus Erlinger, Prof. Franz (Franciscum) Plater, Dr Frederik (Fridericum) Bauhin and Prof. Theodor Zwinger 'der Jüngere', who all, although with some reservation, consented to the ligature procedure that eventually separated the conjoined twin sisters. Emanuel Socin, Christophor Burcard and Daniel Burcard, distinguished members of the city of Basel, witnessed the final surgical procedure. Zwinger mentioned Fatio as the separating surgeon. Van der Weiden (2004) suggests that all these doctors were already deceased in 1689, and for that reason could not have been present during the separation stating that Fatio 'studied their works and meant their consultation as to that in a figurative manner'. But the wrong persons were erroneously mentioned. Theodor Zwinger 'der Aeltere' (1533-1588) was not consulted, but rather Theodor Zwinger 'der Jüngere', who lived from 1658-1724. Theodor Zwinger is the author of the second article

Received 2 August, 2004; accepted 24 August, 2004.

Address for correspondence: Erwin J.O. Kompanje, Department of Neurological Surgery, Erasmus Medical Center Rotterdam, P.O. Box 2040, 3000 CA Rotterdam, the Netherlands. E-mail: e.j.o.kompanje@erasmusmc.nl 


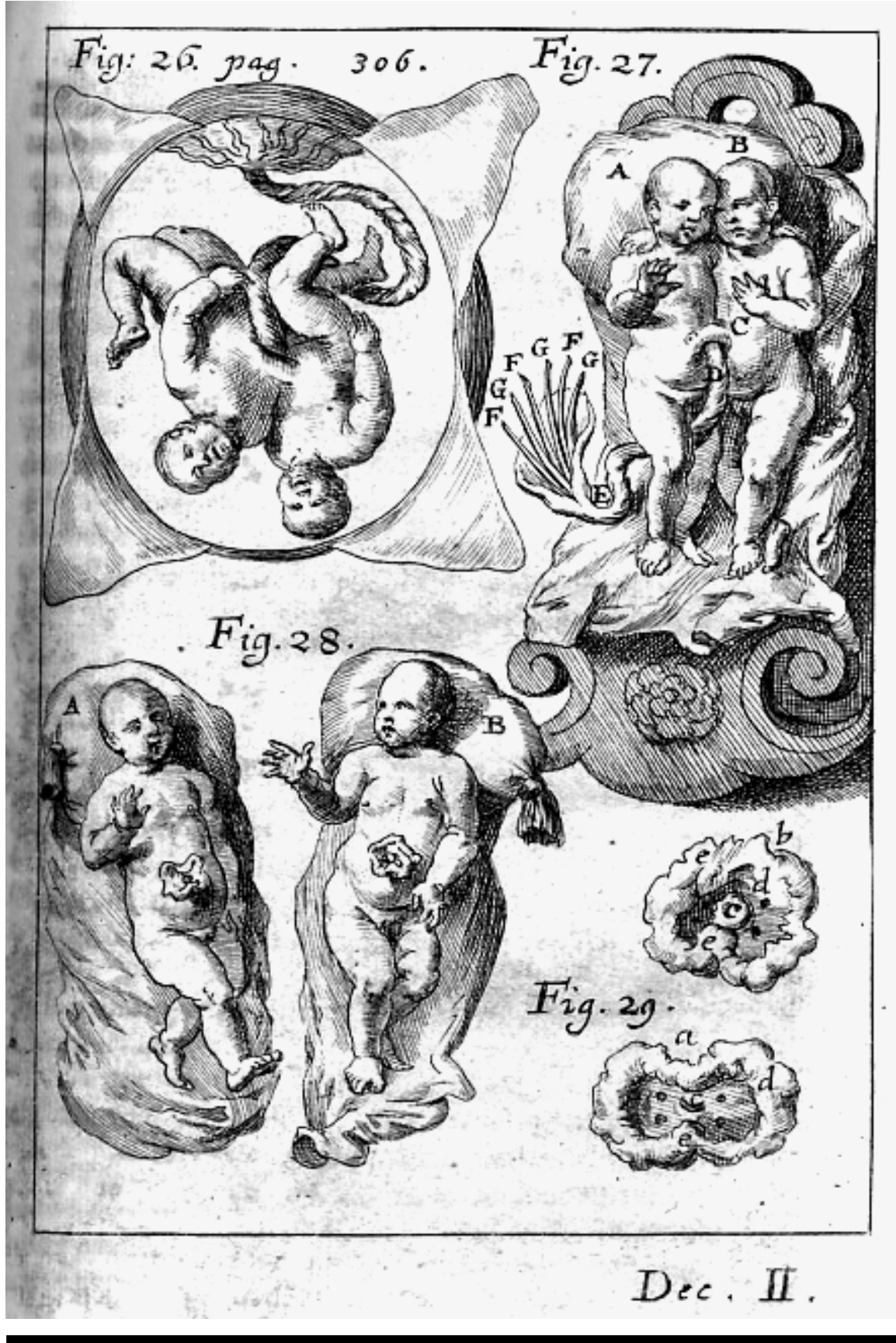

Figure 1

Plate from Koenig (1689). 


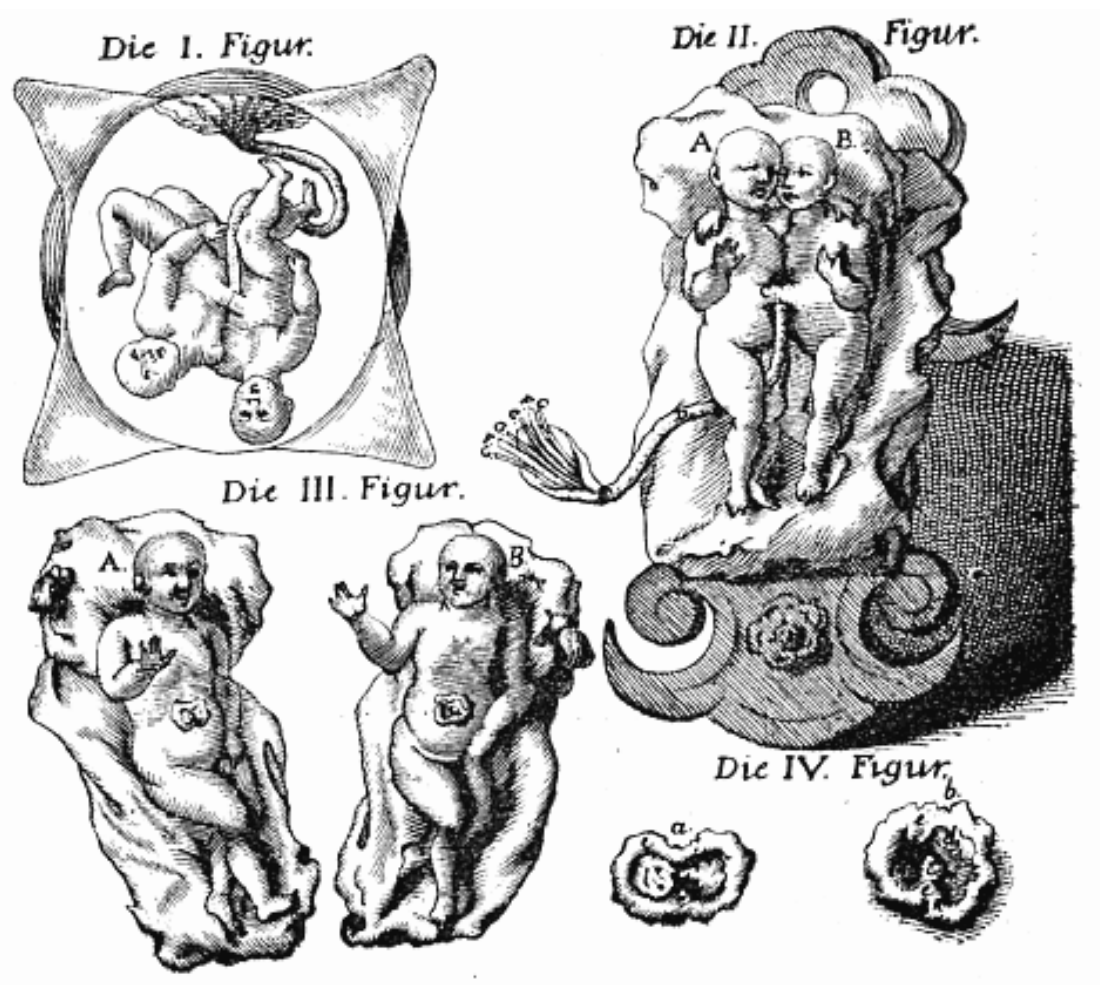

Figure 2

Plate from the Flug Blatt (1689-1695).

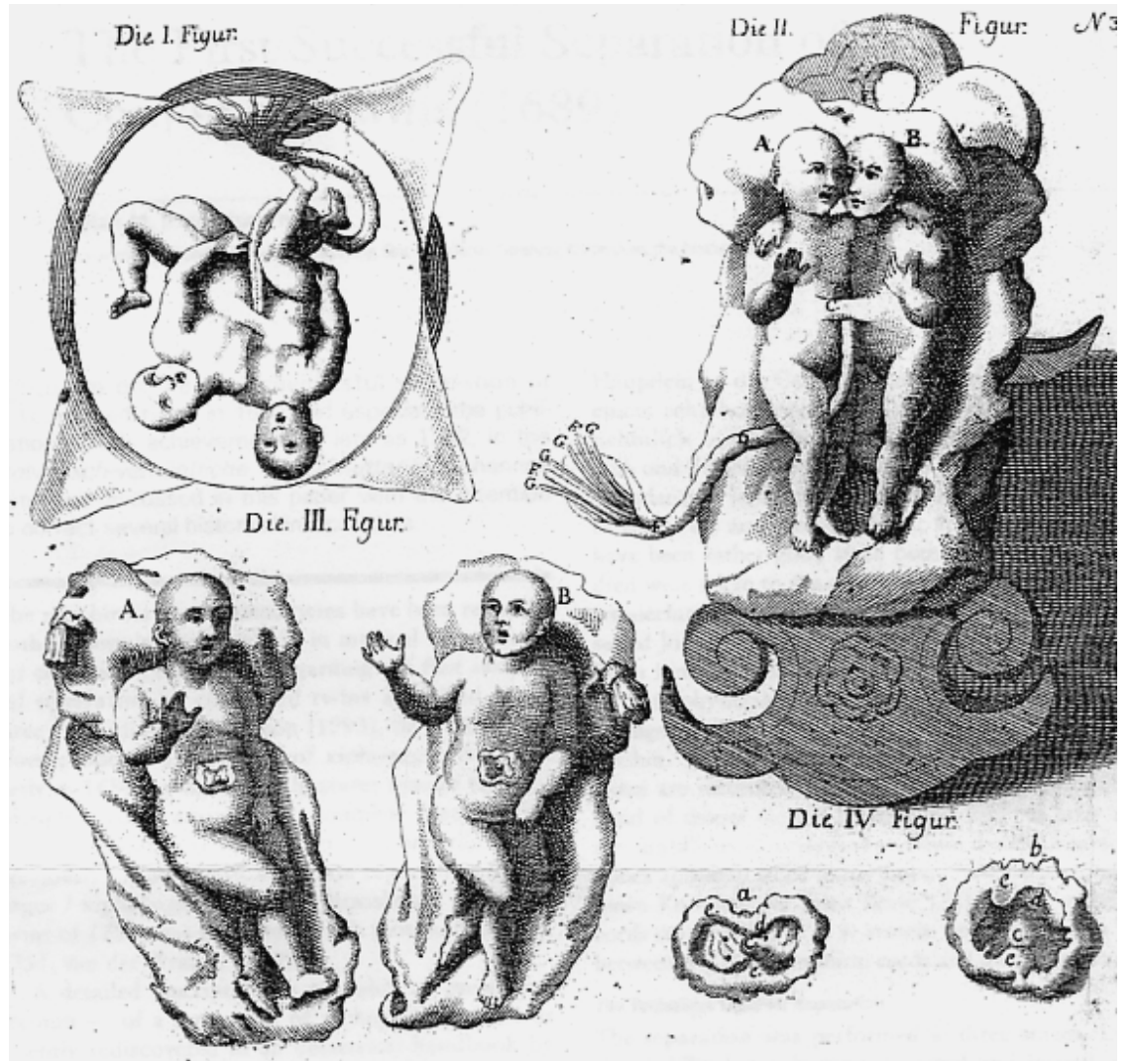

Figure 3

Plate from Fatio (1752). 
on the case (Zwinger 1690). Franz (Franciscum) Plater (1645-1711), a general physician at Basel during his life, was present in 1689, not Felix Plater (1536-1614). Frederik (Fridericum) Bauhin (date of birth and death unknown), son of Johann Caspar Bauhin (1606-1685) and grandson of Caparus Bauhin, was consulted in 1689, not Caparus Bauhin (1560-1624). Nicolaus (Nicolaum) Eglinger (1645-1711), who at that time was Professor of Anatomy and Botany at Basel, was also one of the physicians present. The first article on this case in 1689 was written by Emanuel König (Koenig) who was born in 1658 at Basel and died in 1731 . Following his studies in medicine and philosophy, König became professor of Greek language, physics and theoretical medicine at the University of Basel and was author of many scientific articles, theses and extensive systematic works on zoology, botany and mineralogy, as well as a thesaurus also mentioned by Van der Weiden. He was not just 'one of the anonymous medical doctors present on December, 1689' (Van der Weiden, 2004), but rather one of the more prominent personalities present, and author of the first article on the case.

A third source is a German Flug Blatt (a one-page case report, a short text usually illustrated with an engraving) published between 1689 and 1695. The engraving (Figure 2), with a length of $33 \mathrm{~cm}$ and width of $23 \mathrm{~cm}$ and explicative text, were (made? and) sold by J. J. Thourneyer, Kupferstecher, Kunsthandler und Kupfertrucker in Basel. The Dutch physician De Feyler described the Flug Blatt in 1907, from a copy present at the Leiden University Library in the Netherlands (De Feyler, 1907). This particular Flug Blatt was previously part of the private library of the famous physician Dr J. J. Wepfer (1620-1695), which was bought by the Leiden University at the end of the 18th century. The Flug Blatt is not dated, but it must have been published between 1689, the year of birth of the twins, and 1695, the year in which Wepfer died, most probably shortly after the separation of the twins in 1689. Others, referring to De Feyler's article, also mention details of the text (Anonymus 1907; Schelenz 1909). Beside the information already described by Van der Weiden (2004), particular details were found in the text, such as the fact that both girls were baptised after birth and named Elisabet and Catherina, and that they were taken to the house of Samuel Braun in Eschem near Basel. The text also reveals that Johannes Fatio was the surgeon who performed the actual separation. Figure III in the plates depict Elisabet (A) and Catherina (B) drawn shortly after the baptising.

\section{Other Sources}

Several classic texts on teratology mention the case report in detail. Geoffroy Saint-Hilaire (1836), Vrolik (1840), Förster (1865), Gould \& Pyle (1897), Baudouin (1902) and Scammon (1925) all mention the case history and the separation as described by König and Zwinger. Cesare Taruffi, whose eightvolume history of teratology (Taruffi, 1881-1894) provides many historical sources, discusses the case in detail (Taruffi 1882). Ernst Schwalbe (1907) in his impressive handbook on teratology, cites and illustrates the case and also refers to König. Nichols et al. (1967) and Schumacher (1996) both show a copy of the engraving from König's article and a description of the case. O'Neill et al. (1988), Bondeson (1993) and Van der Weiden (1999) erroneously named König as surgeon. Spencer (2003) in her recent monograph on conjoined twins, mentions the case briefly with some inaccuracies, referring to the two articles in the Deutsche Medizinische Wochenschrift (Anonymus 1907; Schelenz 1909). Rickham (1986) and Spitz \& Kiely (2003) named Fatio as the surgeon and König as the first publisher of the case.

\section{The First Case?}

Is this separation really the first case in history? Theophanes Continuatus offers a detailed description of a surgical separation of conjoined twins in the 10th century in the Corpus scriptorum historiae byzantinae. In 945 the full-grown conjoined twin boys appeared in Constantinople. When one of the boys died, he was separated from the other. The surviving boy lived for three days (Pentogalos \& Lascaratos, 1984). Judging from the description, this case also involved xiphopagus conjoined twins.

\section{Conclusion}

The separation of the xiphopagus conjoined twins by Johannes Fatio in 1689 is well-described in the classic and modern literature. The case appeared in scientific literature on three previous occasions, and approximately 60 years earlier than Fatio's 1752 Arzney Buch. The plates in Fatio (1752) and on the Flug Blatt were copied from the original engraving in the original description by König (1689). Emanuel König, Nicolaus Erlinger, Franz (Franciscum) Plater, Federik (Fridericum) Bauhin and Theodor Zwinger 'der Jüngere' all played an active role in November-December, 1689. The articles by König (1689) and Zwinger (1690) should be cited as the first publications of the successful separation of Elisabet and Catherina, not the book by Fatio (1752). Van der Weiden (2004) and the present article offer a deeper understanding of the events in 1689 and the years thereafter. A successful attempt to separate conjoined twins in 945 A.D. is also known and the separated boy lived for three days.

\section{References}

Anonymus (1907). Xiphopagen. Deutsche Medizinische Wochenschrift, 33, 157. 
Baudouin, M. (1902). Les monstres doubles autositaires opérés et opérables. Revue de Chirurgie, Année, 22, 513-547.

Bondeson, J. (1993). The Isle-Brewers conjoined twins of 1680. Journal of the Royal Society of Medicine, 86, 106-109.

De Feyler, F. M. G. (1907). Een scheiding van xiphopagen in ... 1689. Nederlands tijdschrift voor Geneeskunde, $5,1720-1722$.

Fatio, J. (1752). Der Arzney Doctor, HelvetischVernüftige Wehe-Mutter. Basel, Switzerland: Johann Rudolph Imhof.

Förster, A. (1865). Die Missbildungen des Menschen, systhematisch dargestellt (p. 36). Jena, Germany: Friedrich Mauke.

Geoffroy Saint-Hilaire, I. (1836). Histoire génèrale et particulière des anomalies de l'organisation chez l'homme et les animaux (Traitè de tératologie; p. 84). Tome troisième. Paris: J. B. Baillière.

Gould, G. M., \& Pyle, W. L. (1897). Anomalies and curiosities of medicine (p. 172). Philadelphia, PA: W. B. Saunders.

König, D. E. (1689). Gemelli invicem adnati feliciter separati. Miscellanea Curiosa sive Ephemeridum Medico-Physicarum Germanicarum Academiae Imperialis Leopoldinae Naturae Curiosorum, annus octavus, 305-307.

Nichols, B. L., Blattner, R. J., \& Rudolph, A. J. (1967). General clinical management of thoracopagus twins. Birth defects, 3, 38-51.

O’Neill, J. A., Holcomb, G. W., Schnaufer, L., Templeton, J. M., Bishop, H. C., Ross, A. J., Duckett, J. W., Norwood, W. I., Ziegler, M. M., \& Koop, C. E. (1988). Surgical experience with thirteen conjoined twins. Annals of Surgery, 208, 299-310.

Pentogalos, G. E., \& Lascaratos, G. (1984). A surgical operation performed on siamese twins during the tenth century in Byzantium. Bulletin of the History of Medicine, 58, 99-102.
Rickham, P. P. (1986). The dawn of pediatric surgery. Johannes Fatio (1649-1691): His life, his work and his horrible end. Progress Pediatric Surgery, 20, 94-105.

Scammon, R. E. (1925). Fetal malformations. In I.A. Abt (Ed.), Pediatrics (Vol. VI, p. 654-682). Philadelphia, PA: W. B. Saunders.

Schelenz, C. (1909). Die Trennung von Xiphopagen im Jahre 1689. Deutsche Medizinische Wochenschrift, $35,157$.

Schumacher, G.-H. (1996). Monster und Dämonen. Unfälle der Natur. Eine Kulturgeschichte. Berlin: Edition Q.

Schwalbe, E. (1907). Die Morphologie der Missbildungen des Menschen und die Tiere. II Teil, Die Doppelbildungen (pp. 246-247). Jena, Germany: Gustav Fisher.

Spencer, R. (2003). Conjoined twins (p. 7). Baltimore, MD: John Hopkins University Press.

Spitz, L., \& Kiely, E. M. (2003). Conjoined twins. Journal of the American Medical Association, 289, 1307-1310.

Taruffi, C. (1882). Storia della Teratologia. Parte Prima, Tomo II (p. 521, 527). Bologna, Italy: Regia Tipografia.

Van der Weiden, R. M. F. (1999). Two early reports on conjoined twins. Twin Research, 2, 30-32.

Van der Weiden, R. M. F. (2004). The first successful separation of conjoined twins (1689). Twin Research, 7, $125-127$.

Vrolik, W. (1840). Over dubbelde misgeboorten. Nieuwe verhandelingen van de eerste klasse des KoninklijkNederlandschen instituuts van wetenschappen, letterkunde en schoone kunsten, 9, 1-232.

Zwinger, D. T. (1690). Historia Admirandi Partus Gemellarum Vivarum, umbilicotenus sibi invicem connatarum. Miscellanea Curiosa sive Ephemeridum Medico-Physicarum Germanicarum Academiae Imperialis Leopoldinae Naturae Curiosorum, Annus Nonus, 229-232. 